MARIA VELIZAROVA*

Bulgarian Academy of Sciences

VASSIL KIROV**

Bulgarian Academy of Sciences

https://doi.org/10.26485/PS/2018/67.3/3

\title{
LABOUR EXPLOITATION \\ OF BULGARIAN MIGRANTS IN EUROPE: COPING MECHANISMS ${ }^{1}$
}

\begin{abstract}
Labour exploitation and its extreme forms, such as forced labour and trafficking of human beings, are not new phenomena. They are also present throughout Central and Eastern Europe and Bulgaria in particular. This article explores the mechanisms used by workers to overcome these challenges on the labour market. The analysis is based on qualitative interviews with low-skilled Bulgarian migrants in EU countries. Strong social networks used during the first migration action are considered as a mechanism which mitigates the risks of exploitation.
\end{abstract}

Keywords: labour exploitation, precarious work, migration, Bulgaria, vulnerability, social networks

* TPhD student, Institute for the Study of Societies and Knowledge; e-mail: mariavelizarova@yahoo.com

** Associate Professor, Institute for the Study of Societies and Knowledge; e-mail: vassil.kirov@gmail.com

${ }^{1}$ This article is part of a PhD project carried out by Maria Velizarova and her supervisor, Dr Vassil Kirov, which investigates the labour experiences and precarious situations of Bulgarians abroad, which could lead to labour exploitation. 
"Low payment, labour exploitation, avoiding the labour law: the German slaughterhouses use subcontracted workers, mainly from Eastern Europe. They are making big profits of their labour" [Fakti BG, 16.05.2017]

\section{INTRODUCTION}

Labour exploitation and its extreme forms, including forced labour, severe labour exploitation, and trafficking of human beings, are not new phenomena, but there is increasing awareness about their development. While it might seem surprising, such phenomena are observable in Europe [FRA 2015; Walk free 2016]. Bulgaria is an example of such a case, however, there are different estimations of the scope and number of those involved in labour exploitation. Numerous Bulgarian citizens working in other EU countries, especially since the EU accession in 2007, are being exploited and this is broadly covered by the media. Labour exploitation is defined by the European Union Agency for Fundamental Rights [FRA 2015:10] as: "work situations that deviate significantly from standard working conditions as defined by legislation or other binding legal regulations, concerning in particular remuneration, working hours, leave entitlements, health and safety standards and decent treatment".

Although there is an important research stream on precarious work and its rise, labour exploitation is understudied. Our research aims at filling the knowledge gap by analysing the case of Bulgarian citizens working in other European Union (EU) countries, and we focus on the mechanisms used by them to overcome associated risks. The initial assumption is that if workers hold a precarious position on the labour market and are subject to further risk factors (factors that render workers more vulnerable to labour exploitation) [FRA 2015: 9] before their first migration action, there is a higher probability of them falling into the trap of labour exploitation abroad. This pilot study is based on in-depth interviews investigating the factors leading to workers' vulnerability [Ranci 2011], among them: type of household, employment status, educational level, economic and social situation in their region of origin, as well as the available opportunities and mechanisms to overcome these challenges.

The limited administrative or statistical data on labour exploitation raises a number of methodological challenges. There is a lack of reliable and systemised data about problematic labour experiences among Bulgarian workers abroad or about circular and temporary migration. Such methodological challenges are common in the exploration of migration from CEE countries to other EU countries, 
where their undocumented residence is common [Engbersen et al. 2013; Kaczmarczyk et al. 2005]. We carried out in-depth interviews with Bulgarian citizens who have work experience in other EU countries. This experience was often accumulated during multiple stays abroad, either in the context of temporary or circular migration. We focused on their first labour experience abroad, as at that point there is a larger risk of exposure to potential exploitation. We chose our respondents from regions in Bulgaria with high unemployment rates and a concentrated population with low education and qualification levels, all of which imply a heightened risk for vulnerabilities on the labour market. Their work abroad is considered an escape from financial hardships in Bulgaria. Studies on this group are often conducted in the country of destination [Markova et al. 2007]. Here, an additional contribution is to analyse their experience from the perspective of the country of origin.

After discussing the theoretical background in the first section, the article presents the empirical findings of the study in the second section and discusses them in the third section in the context of the literature. The final section concludes the paper.

\section{THEORETICAL BACKGROUND}

Labour exploitation of the migrant workforce is often approached from research perspectives concerned with labour and human rights, e.g., in labour law studies or in migration studies [McKay et al. 2012, McCann et al. 2017], but rarely within the framework of the sociology of work. There are a multitude of reasons for this, including difficult access to those groups and their marginalised position, as well as not uncommon participation in the informal economy or informal employment arrangements. We argue that labour exploitation represents an exacerbated form of precariousness, and from this perspective it is useful to refer to the larger body of research on precarious work in Europe. As vulnerability is one of the main aspects of precariousness and migrant workers are seen as one of the most vulnerable groups, we will take a closer look at migration research in Europe with a focus on internal EU migration.

\section{Labour exploitation as an extreme form of precarious work}

Multiple definitions of precarious work have been formulated in recent years, both in academia [Evans et al. 2009; Keller et al. 2013; Standing 2011] and by policyoriented institutions [ILO 2009; European Parliament Committee on Women's 
Rights and Gender Equality report 2010; FRA 2015]. These definitions stress the uncertainty that can contribute to feelings of powerlessness to act and claim one's labour rights. For example, Keller et al. [2013] argue that the indicators of precarious work include: low job security; limited or no social security entitlements; hindered access to training or skills development; limited access to training, holidays and collective benefit entitlements, and paid overtime; and abuse of travel reimbursements, among others. Precarious work is seen as a deviation from standard employment practises and standard working contracts for workers and employees. As is evident in Table 1, most of the elements of precarious work are similar to the elements of labour exploitation. There are also differences: in the case of labour exploitation, there are always violations of legal norms and laws [ILO 2009], while under precarious employment there are no criminal violations, but labour legislation could be breached. Still, this understanding might be challenged due to the fact that not every deviation from a typical contract work arrangement necessitates a negative effect on precariousness and, moreover, it is possible for typical employment contracts to incorporate precarious practices, as well [Trif et al. 2016; Keller et al. 2013].

TABLE 1. Indicators of labour exploitation and precarious work

\begin{tabular}{|c|c|c|c|c|c|}
\hline $\begin{array}{c}\text { Labour } \\
\text { Exploitation } \\
\text { indicators } \\
\end{array}$ & $\begin{array}{c}\text { ILO } \\
\text { [2009] }\end{array}$ & $\begin{array}{c}\text { FRA } \\
{[2015]}\end{array}$ & $\begin{array}{l}\text { Precarious Work } \\
\text { indicators }\end{array}$ & $\begin{array}{c}\text { Keller and } \\
\text { Seifert } \\
{[2013]} \\
\end{array}$ & $\begin{array}{c}\text { Evans and } \\
\text { Gibb [2009] }\end{array}$ \\
\hline Low or no salary & $\mathrm{X}$ & $\mathrm{X}$ & Low salary & $\mathrm{X}$ & $\mathrm{X}$ \\
\hline $\begin{array}{l}\text { Wage } \\
\text { manipulation }\end{array}$ & $\mathrm{X}$ & & $\begin{array}{l}\text { Limited access } \\
\text { to holiday and } \\
\text { collective benefit } \\
\text { entitlements and } \\
\text { paid overtime; } \\
\text { abuse of travel } \\
\text { reimbursements }\end{array}$ & $\mathrm{X}$ & $\mathrm{X}$ \\
\hline $\begin{array}{l}\text { Excessive working } \\
\text { days or hours }\end{array}$ & $\mathrm{X}$ & $\mathrm{X}$ & Long working hours & $\mathrm{X}$ & \\
\hline $\begin{array}{l}\text { Poor living } \\
\text { conditions }\end{array}$ & $\mathrm{X}$ & $\mathrm{X}$ & & & \\
\hline Hazardous work & $\mathrm{X}$ & & & & $\mathrm{X}$ \\
\hline $\begin{array}{l}\text { Very poor working } \\
\text { conditions }\end{array}$ & $\mathrm{X}$ & $\mathrm{X}$ & \begin{tabular}{|l|} 
Poor working \\
conditions
\end{tabular} & $\mathrm{X}$ & $\mathrm{X}$ \\
\hline $\begin{array}{l}\text { No access } \\
\text { to education }\end{array}$ & $\mathrm{X}$ & & $\begin{array}{l}\text { Hindered access } \\
\text { to training and skills } \\
\text { development }\end{array}$ & $\mathrm{X}$ & \\
\hline
\end{tabular}




\begin{tabular}{|l|c|c|c|c|c|}
\hline $\begin{array}{c}\text { Labour } \\
\text { Exploitation } \\
\text { indicators }\end{array}$ & $\begin{array}{c}\text { ILO } \\
{[2009]}\end{array}$ & $\begin{array}{c}\text { FRA } \\
{[2015]}\end{array}$ & $\begin{array}{c}\text { Precarious Work } \\
\text { indicators }\end{array}$ & $\begin{array}{c}\text { Keller and } \\
\text { Seifert } \\
{[2013]}\end{array}$ & $\begin{array}{c}\text { Evans and } \\
\text { Gibb [2009] }\end{array}$ \\
\hline $\begin{array}{l}\text { No social } \\
\text { protections } \\
\text { (contract, social } \\
\text { insurance) }\end{array}$ & $\mathrm{X}$ & $\mathrm{X}$ & $\begin{array}{l}\text { Limited or no social } \\
\text { security entitlements }\end{array}$ & $\mathrm{X}$ & $\mathrm{X}$ \\
\hline $\begin{array}{l}\text { No respect } \\
\text { of labour laws } \\
\text { or contract signed }\end{array}$ & $\mathrm{X}$ & $\mathrm{X}$ & & & \\
\hline
\end{tabular}

Source: Authors' own compilation

The main similarity between precariousness and exploitation is that in both cases somebody takes unfair advantage of a worker. In the case of exploitation, the vulnerabilities of the exploited person are used for the benefit of someone else [Zwolinski et al. 2017]. Zwolinski identifies two approaches for exploring exploitation, transactional and structural [2017]. The former considers the case of unfair transactions between two or more individuals, while the latter points to the unfairness of the system which has set rules that benefit one part of society to the disadvantage of another [2017]. As Zwolinski points out, Marxian theory focuses on the second (structural) approach, considering workers' labour under the capitalist system as neither truly voluntary nor entirely for the benefit of the workers [2017]. In this article we focus on the transactional approach. In narrowing the theoretical discourse on labour exploitation, we now focus on the established legal framework which reflects it and is used within the EU.

The discourse on precarious work in Europe gained particular importance in response to the start of the 2007-2008 financial crisis. The transfer of economic risk from the state to the private sector results in deregulation of labour markets, providing fruitful ground for the development of precarious work practices [Beck 2000]. More recently, Stone [2005] suggests that both the state and businesses are involved in the process of weakening labour rights or at least ignoring them; there are studies confirming this exacerbation of the problem and thus supporting Beck's observations. A recent study by Trif et al. [2016] points out that all forms of employment in ten researched CEE countries and Greece have been exposed to the precarisation of labour conditions and that this has been followed by various degrees of labour market deregulation and a subsequent negative effect on workers' labour rights. In particular, the authors observe wage decreases, an increase in unpaid additional working hours and irregular working hours, and 
the introduction of new labour regulations which weaken protective mechanisms for employees. These trends are increasing the vulnerability of workers and employees in general and, simultaneously, open the door for their exploitation. Still, particular groups could be exposed to higher degrees of vulnerability risk [Kirov et al. 2015]. These could be well-known groups or less visible ones, but it is certain that less-educated and less-qualified migrant workers are among them. A migrant's country of origin can increase person's risk of being exploited. This is the case for CEE countries where an institutional asymmetry exists between the codified laws and regulations of formal institutions and the socially shared unwritten rules of informal institutions [Williams et al. 2015]. All structural conditions, including inadequate state interventions and protections for workers, are seen as indications of such institutional asymmetry [Williams et al. 2015]. This leads to precarious work and the inability of state mechanisms to protect workers.

Following the different theoretical explanations of precarisation and exploitation, we can conclude that the precarisation of labour increases risk factors for labour abuse and can lead to labour exploitation and its severe forms. Especially vulnerable to such practices are migrant workers coming from countries with deregulated labour markets.

\section{Vulnerability and Migration}

Theories about migration and the rise of the international flexibilisation of labour markets have begun taking into consideration the increase of labour force vulnerability, especially in light of the world financial and economic crisis that started in 2007-2008. Even if the indicators of both precariousness and labour exploitation are similar, there is a visible distinction regarding workers' vulnerabilities - precarisation leads to their increase and exploitation is the act of taking advantage of them. Precariousness also has a macro-level perspective that may produce inequality, instability, and insecurity, which can in turn make workers more vulnerable on the labour market [Trif et al. 2016]. In this situation, workers fear losing their jobs and have a strong feeling of labour insecurity. The lack of alternatives and opportunities increases workers' uncertainty and thus their vulnerability [Trif et al. 2016], which then can be taken advantage of and abused through exploitative practices on the labour market. Vulnerability can also be affected by macro and micro factors, such as type of household, employment status, educational level and economic and social situation in the region of origin [Ranci 2011]. With the increase of these vulnerability risk factors for workers, the probability of their being taken advantage of increases, too [Williams et al. 2015], 
leading to potential labour exploitation. From this perspective, the precarisation of work is a gateway to labour exploitation.

There is a consensus in the literature that migrants in general are one of the most vulnerable groups on the labour market, as they share multiple vulnerability indicators [McKay et al. 2012; McCann et al. 2017]. For example, a recent study by Aleksynska et al. [2017] shows that most migrants with Asian origins in Europe suffer frequently from deficits in their working conditions in terms of contractual status, remuneration amount and periodicity, hours worked, and occupational safety and health issues. In line with these outcomes, we focus on Bulgarians with labour experience in other EU countries as well as job risk factors preceding their first migration departure. Migrants in low-skilled jobs are especially vulnerable, as shown in the case of migrants from the CEE region to other EU countries [Engbersen et al. 2013].

King [2012] suggests that a multi-theoretical approach is needed in order to understand such a complex phenomenon as migration. Thus, the "New Economics of Labour Migration" [Stark 1991] and theories of migration systems and networks are most appropriate for exploring the specific characteristics of the group under study. The New Economics of Labour Migration (NELM) combines economic motivations with personal reasons behind migration decisions. These decisions are conceptualised as family decisions rather than individual ones, where the family takes steps together to minimise the overall risk to the migration action of one family member. This approach frames migration as a dynamic process and not a permanent step towards relocation. In addition to NELM, theories of migration systems and networks also contribute to the better understanding of various macro and micro factors which influence the migration process [King 2012] and are used in our specific case as mechanisms which influence the risks of labour exploitative practices. For Massey [1993], migration networks are the social capital which facilitates international movement and provides information which can minimise the risk of migration actions. According to Boyd and Novak [2012], each type of network influences the risk posed by migration, either positively or negatively. The mainstream view of migration networks is that they have a positive influence over the process of migration in that they provide the information and contacts needed for orientating the person who intends to migrate. They can assist migrants in organising their journeys and, later on, in settling within the host country [Granovetter, 1973]. Granovetter [1973] makes a distinction between 'weak' and 'strong' informal ties and the role they play in migration actions. He considers 
weak ties to be more effective for passing on information about job opportunities to a larger number of people as compared to strong ties.

Social networks also can have a negative influence on migration actions, e.g., the wilful misleading and deception of potential migrants, which in extreme cases can lead to illegal and criminal activities such as trafficking of people [Samers 2010]. Taking into consideration Boyd and Novak's social migration network [2012] and the categorisation of strength in social networks by Granovetter [1973] and Samers [2010], we distinguish between strong, medium, and weak social migration networks in order to explore them as possible mechanisms for risk mitigation. Strong networks include family and close friends (people who the respondent knows very well, sharing a high level of mutual trust and reciprocal services). Medium-strength networks consist of friends, colleagues, and neighbours (common interests and occasional reciprocal services). Weak networks are built upon acquaintances (absence of social ties). The relevance of social networks among labour migrants from CEE countries to other EU countries, and in particular Bulgaria, has also been suggested in other labour migration studies in the region [Engbersen et al. 2013].

The choice of NELM and theories of migration systems and networks are particularly relevant in the European Union context. Internal EU migration has more of a temporal character and social networks here play an important role in migration actions, defined as the decision to migrate and the actions taken to migrate [Eurofound 2014]. Migration tendencies from Bulgaria to other EU countries do not deviate from the above-mentioned EU norms. Around $70-80 \%$ of Bulgarians involved in migration select other EU member state countries as their destination [Alpha Research 2015] and are often involved in seasonal or circular migration schemes [Krasteva 2006]. Temporary migration represents a large part of migration flows in general, as between 20 and 75 percent of immigrants leave OECD host countries within the first five years after arrival [OECD 2008]; for all included European countries, the return rate is around 50 percent. Temporary migration may take more complex forms than simple return migration [Dustmann et al. 2015]. It can include forms of repeated or circular migration, undocumented migration, student migration, and guest worker migration. The length of stay abroad, as Dustmann et al. [2015] suggest, also influences migrants' behaviour in relation to their savings plans and desire to learn the local language. Migrants with shorter stays typically have lower reservation wages and accept jobs that would not be acceptable if their immigration was permanent. 
The literature review allowed us to discuss the characteristics of precarious work and labour exploitation (Table 1) and analyse the relationship between both concepts. Precarisation leads to a person's increased vulnerabilities, which then can be exploited through the act of taking advantage of them. In comparison to precarious practices, exploitative ones are always connected with violations of labour regulations and laws. The question is, how can we better understand the mechanisms used to overcome risk factors leading to labour exploitation? As social networks are considered to be one such mechanism, and the Eurofound [2014] data confirms their frequent utilisation in migration decisions and actions within Europe, we shall explore how the networks used by Bulgarian migrants have influenced their labour migration experiences. Taking into consideration the strength of networks used by our respondents, we will compare their subjective labour experiences with the objective indicators of labour exploitation [ILO 2009] as well as the role of network strength in minimising or amplifying risk in initial migration actions. Though we are aware that there are differences among the destination countries and their labour markets, our small sample size will not allow us to tackle these. However, due the late entry of Bulgaria and Romania in the EU (2007) and the late opening of the labour markets of some EU countries to Bulgarians and Romanians (e.g., 2014 for the UK), their labour migration (especially low-skilled migration) to Southern Europe was more common than to Western Europe before 2014.

\section{METHODOLOGY}

Obtaining reliable data on migrant labour exploitation is challenging. Many cases of temporary or circular migration are not recorded in official statistics [Alpha Research 2015]. Very often the affected employees are involved in informal or semi-formal relations with their employer and are not willing to disclose their experience. While cases of forced labour and human trafficking are often portrayed in the media and identified by state agencies and NGOs, many employees suffering labour exploitation rarely make official complaints because of fear and shame [FRA 2015]. In addition, Bulgarians show increasing distrust in public institutions and their ability to provide adequate support, and this can be seen as another reason for the low number of such cases being reported. That is why we have adopted a qualitative research approach [Flick 2009] to examine labour exploitation alongside an inductive approach [Abrams 2010] and in-depth interviews. Collecting stories about the work experiences of Bulgarians in their 
home country and outside of it enables a better understanding of precarious labour situations and how they have led to labour exploitation practices following the first migration action in other EU countries.

The respondents were selected using three criteria for vulnerability on the labour market, as discussed in the theoretical section of this paper: low education, overall high regional unemployment, and high regional poverty levels [McKay et al. 2012; FRA 2015]. As the Bulgarian macroeconomic data suggests, there is a positive correlation between regional levels of unemployment, poverty, and low education [Nikolova et al. 2016]. Thus, the interviews were conducted in three of the least developed administrative districts ${ }^{2}$ in Bulgaria, the cities of Sliven, Jambol and Targovishte.

Labour exploitation is a sensitive topic for respondents. It can be seen as a personal failure and can provoke sustained feelings of shame as well as an unwillingness to share information about such experiences. This is the reason why direct questions about exploitation were avoided during the interviews. The in-depth interview guide included more general questions about work experience both in Bulgaria and abroad. In this way, we explored their subjective experiences of work and were able to assess this against the ILO indicators of labour exploitation [2009]. As suggested elsewhere [FRA 2015], no two people's experiences of labour exploitation are the same, and being in an exploitative situation is often preferable to being unemployed and penniless in the home country.

Access to respondents was secured through a purposive sampling strategy, informed by the theoretical concept of vulnerability [Abrams 2010]. We made the informed choice to focus on respondents coming from less economically developed regions in Bulgaria where the probability of risk factors for potential labour exploitation is higher. This method of sampling is in conformity with the explorative character of our research. For the purposes of this paper, we carried out 13 in-depth interviews. The recruitment of respondents was facilitated by the local coordinators of a large Bulgarian survey company known for their selection experience and good district knowledge. The interviews were transcribed and narratively analysed [Flyvbjerg 2006]. The selection was based on demographic criteria (gender, age, and education), allowing us to incorporate more diverse cases and observe generational and gender differences. Not surprisingly, a large amount

2 Bulgaria has 28 administrative districts. They differ in their economic development and population density and profile. 
of those meeting the selection criteria belonged to the two main minority groups ${ }^{3}$ in Bulgaria, Turks and Roma. Their innate suspicion of 'strangers', coupled with low education levels and sometimes language problems (in Bulgarian), represented an additional barrier to the field research. We interviewed four people in the region of Jambol, five in the region of Sliven, and four in the region of Targovishte. Six of them were female and seven were male. Table 2 presents the respondents' distribution according to age, education, ethnicity, work sector abroad, and first country of labour migration:

Most of our respondents have worked in the agricultural sector abroad (eight of 13). Our sample also included one woman who was a housekeeper, a man who worked in a factory, two women whose first jobs were in the cleaning sector, and a man who worked in a restaurant kitchen. Agriculture and housekeeping are often seen as sectors with a high occurrence of exploitation and precarious working conditions [McKay et al. 2012]. Our respondents have worked in Greece $(n=3)$, Cyprus $(n=3)$, Spain $(n=3)$, Germany $(n=2)$, the UK $(n=1)$ and the Czech Republic $(\mathrm{n}=1)$.

\section{EXPLOITATION AND MIGRATION NETWORKS}

We present our findings, taking into consideration individual vulnerability indicators such as employment status and financial situation at the time of respondents' first departure and the social networks used in the host country (Table 2). Only one respondent experienced none of the exploitation indicators listed by the ILO [2009] during his first labour experience abroad (Table 2). Ten respondents experienced more than four indicators of labour exploitation, whereas three of them reported between eight and nine (the maximum number). These results provide a clear indication as to the relevance and scale of labour exploitation and also contribute to distinguishing the different stages of the phenomenon. Low-skilled labour migrants from Bulgaria to other EU countries are at risk of exploitation. When the respondents were explaining their motivation for migration, it became clear that their precarious situation in Bulgaria was one of the main push factors for their departure. This precarious labour situation before departure was also characterised by risk factors of further labour exploitation abroad.

3 The largest minority groups in Bulgaria are the Turkish ethnic minority, $7.98 \%$, and the Roma ethnic minority, 4.9\% (NIS 2011). One person from the Roma minority and seven from the Turkish minority group are in this sample. 


\begin{tabular}{|c|c|c|c|c|c|c|c|c|c|c|c|c|c|}
\hline 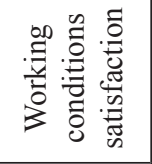 & \begin{tabular}{|c|} 
\\
0 \\
0 \\
-1
\end{tabular} & $\frac{\text { है }}{3}$ & 童 & 容 & .5 & 点 & 昰 & 点 & 吾 & $\underset{\Xi}{\stackrel{\Xi}{\Xi}}$ & 㺃 & .50 & 3. \\
\hline 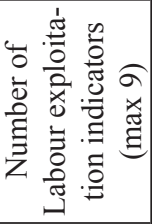 & $\mid$\begin{tabular}{c|c}
0 \\
0 \\
0 \\
0 \\
0 \\
0 \\
0 \\
0 \\
0 \\
0 \\
0
\end{tabular} & $\underset{\nabla}{\stackrel{\Xi}{\Xi}}$ & $\mid$\begin{tabular}{l|}
$\frac{y}{\pi}$ \\
0 \\
3 \\
2 \\
0 \\
0 \\
-1
\end{tabular} & $\begin{array}{l}\infty \\
0 \\
0 \\
0 \\
\infty \\
0 \\
0 \\
\infty \\
\infty\end{array}$ & 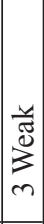 & $\mid \begin{array}{c}0 \\
\tilde{z} \\
z \\
0\end{array}$ & 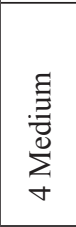 & 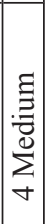 & 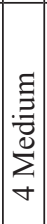 & 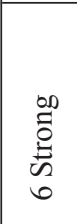 & $\sum_{n}^{\Xi}$ & $\sum_{n}^{\Xi}$ & $\begin{array}{l}\infty \\
0 \\
0 \\
5 \\
\infty \\
2 \\
0 \\
\infty \\
\infty\end{array}$ \\
\hline 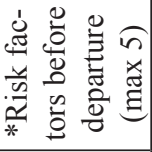 & $m$ & $\sim$ & $\sim$ & $\nabla$ & - & $N$ & $\sim$ & $N$ & $\sim$ & $n$ & $m$ & $m$ & $m$ \\
\hline 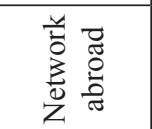 & 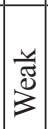 & $\begin{array}{l}\infty 00 \\
\text { Dే } \\
\stackrel{\Xi}{5}\end{array}$ & 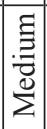 & $\sum^{\frac{y}{\pi}}$ & $\mid$\begin{tabular}{c|}
0 \\
0 \\
0 \\
0 \\
0 \\
$\infty$ \\
$\infty$
\end{tabular} & 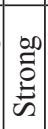 & $\begin{array}{l}00 \\
\tilde{0} \\
\stackrel{\Xi}{E}\end{array}$ & 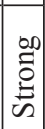 & 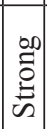 & 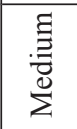 & 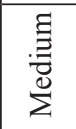 & 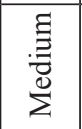 & $\frac{\breve{d}}{3}$ \\
\hline 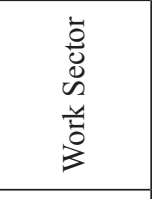 & 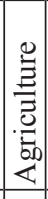 & 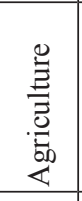 & 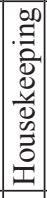 & 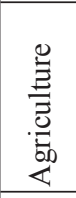 & 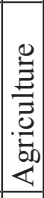 & 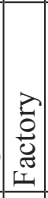 & 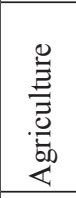 & 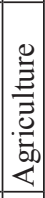 & 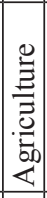 & 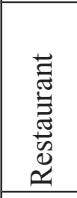 & $\begin{array}{l}\stackrel{\infty}{\Xi} \\
\stackrel{\Xi}{\Xi} \\
\stackrel{\Xi}{\Xi} \\
\end{array}$ & $\stackrel{\infty}{\Xi}$ & 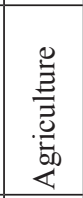 \\
\hline 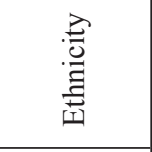 & 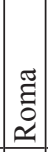 & 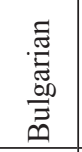 & 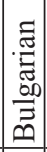 & 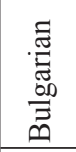 & 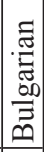 & 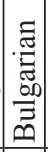 & 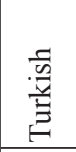 & 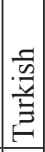 & 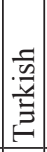 & 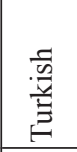 & 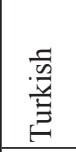 & 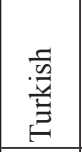 & 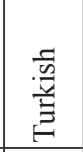 \\
\hline 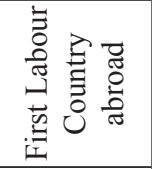 & 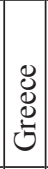 & $\begin{array}{l}0 \\
0 \\
0 \\
0\end{array}$ & 莞 & 总 & 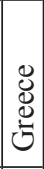 & 总 & $\begin{array}{l}\text { ज्ञ } \\
\text { की }\end{array}$ & 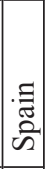 & 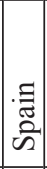 & $\begin{array}{l}\overrightarrow{\vec{E}} \\
\overrightarrow{0} \\
\overrightarrow{01} \\
\overrightarrow{ \pm}\end{array}$ & 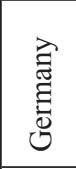 & 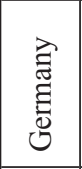 & 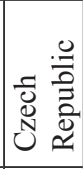 \\
\hline 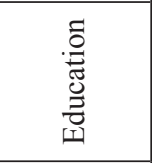 & 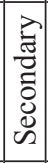 & 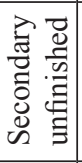 & 预 & 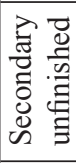 & 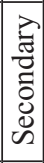 & 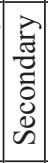 & 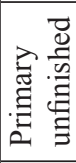 & 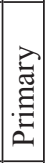 & 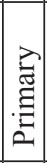 & 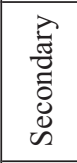 & 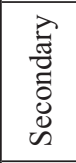 & 预 & 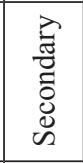 \\
\hline $\mathbb{\infty}_{0}^{\infty}$ & 8 & $m$ & in & ले & fo & 㱏 & ป & $\begin{array}{l}0 \\
\cdots\end{array}$ & $\bar{n}$ & ते & $\stackrel{\infty}{n}$ & f & $\stackrel{\lambda}{ }$ \\
\hline$\stackrel{\dot{J}}{\stackrel{d}{0}}$ & $\sum$ & $\Sigma$ & 工 & I & 工 & $\Sigma$ & L & $\Sigma$ & $\Sigma$ & $\Sigma$ & 山 & 山 & $\Sigma$ \\
\hline 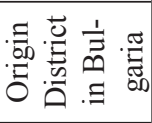 & 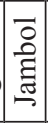 & $\begin{array}{l}\text { ర్ } \\
\text { ह్ } \\
\text { है }\end{array}$ & 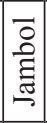 & $\begin{array}{l}\text { Dे } \\
\text { 葛 }\end{array}$ & 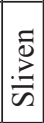 & $\mid \begin{array}{c}\overline{0} \\
. \grave{\Xi} \\
\bar{\varpi}\end{array}$ & $\stackrel{\overline{0}}{\stackrel{\Xi}{\varpi}}$ & 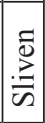 & : & 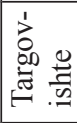 & 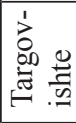 & 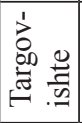 & 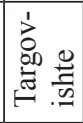 \\
\hline$\stackrel{1}{~}$ & -1 & $N$ & $m$ & $\nabla$ & in & 0 & $r$ & $\infty$ & $a$ & 으 & $=$ & $\simeq$ & 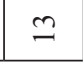 \\
\hline
\end{tabular}




\section{Precarisation and the labour market in the home country}

All our respondents were motivated to leave Bulgaria due to financial difficulties: unemployment or unstable employment, changing jobs, temporal contracts or no contracts at all, low wages, and problematic loans. The respondents over 40 years of age stated that following the political changes in 1989 they had problems finding a stable job. The younger respondents, who entered the labour market in the 1990 s or the first decade of the $21^{\text {st }}$ century, also experienced great instability with regular periods of unemployment and frequent job fluctuations before their first departure abroad.

All the respondents went to work abroad in order to earn money and overcome their financial difficulties in Bulgaria. None of them had a plan for permanent migration from their earliest departure:

I went there for the money, not to stay. (Interview 6)

From this perspective, most of them considered engaging in temporal/seasonal migration.

Most of the respondents were satisfied with their work experience abroad, but their satisfaction is based mainly on the fact that they were able to earn more there in comparison to Bulgaria. Other elements of working conditions, such as working without a day off for long periods or working over 12 hours a day, did not bother them so long as they were getting the promised payment. For those engaged in circular or seasonal labour abroad, the income earned was sufficient to sustain their needs in Bulgaria between seasonal labour activities:

there is no point. (Interview 7)

working in Bulgaria, as payments are too low, and just one month of hard work abroad when a person is:

clever about their finances. (Interview 5)

can allow him/her to live a normal life in Bulgaria for a longer period. This attitude was shared by all of the seasonal workers surveyed.

Almost all of the respondents stated that they would prefer to live and work in Bulgaria if it was possible to achieve the same financial stability as abroad. However, for most of them, the prospects in Bulgaria are still very insecure:

I think of having children, but I do not know if I can afford having one. (Interview 6) 
In addition, they shared their concerns about the difficult access to and reduced quality of the health and social systems in Bulgaria. Some of them were able to compare these to their experience in other EU countries:

it is nothing like here. From the first step in the hospital, I was treated well and all kinds of examinations were done. (Interview 11)

They shared that medical treatment abroad was given freely when needed, even with no health insurance. Despite having paid their social security contributions in Bulgaria, they had to pay out of pocket for each visit to a doctor in the home country. Some of the respondents over 40 shared concerns about their retirement:

I have 20 years till I retire. I do not know how and if we will make it to get a pension. (Interview 5)

The insecure labour market in the home country was a very important topic for the respondents. Some of them shared precarious working experiences they had in Bulgaria before and after their stays abroad: extensive working hours, delayed wages, unwillingness of the employers to pay their social and health insurance, lack of contracts, and the generally insecure nature of their employment.

It was like that back then. If you do not take the work, somebody else will take it, even if you knew the conditions are not very good. (Interview 6)

With my wages back then, I could not take care of my children. If I had had a choice, I would not have left. (Interview 12)

The respondents described not only their precarious (or exploitative) situations on the labour market in Bulgaria and high levels of vulnerability, but also their lack of trust in the protective mechanisms of state institutions in Bulgaria, which only resulted in their increased insecurity on the labour market and their precarious labour situation.

I did so many trainings at the labour office agency, but I did not get a stable job. (Interview 1)

Here I have to pay. If my son breaks his arm and I go the doctor, we have to pay additional fees even if we have health insurance. (Interview 5)

The main feelings of the respondents towards the state in Bulgaria were of disbelief, a lack of hope for things to change, and deep insecurity:

I do not believe, not anymore... I do not hope anymore. (Interview 1)

I see what happens on TV every day and I am constantly concerned about my children when they are not home, if they are safe. It is worse than being in prison. (Interview 5) 
I do not see any future here. (Interview 12)

Here nothing works. (Interview 13)

Six of our respondents who have not worked abroad for the last several years said that they are willing to go abroad again, with the exception of one, aged 61, who said,

it is too late for me. (Interview 1)

Two of them had more concrete plans for leaving Bulgaria in the near future at the time of the interview. All the others had already planned their next working trip abroad.

\section{Precarisation experienced on the labour market in other EU countries}

In the context of lacking faith in Bulgarian state institutions due to their inability to provide basic social services and protection, the individual mechanism to cope with a situation of vulnerability has been via migration to enter the labour market of other EU countries (old member states). However, respondents are aware that the labour markets of some EU countries, especially those in Southern Europe, are also experiencing a rise in precarisation. Three of our respondents left their seasonal occupations in Spain for jobs in England around 2010, when the availability of positions in Spain was scarce and payments were low. Another respondent with more than 20 years of seasonal work experience in Greece stopped working abroad in 2010 because of the decrease in payment offered and significant competition with other migrants looking for jobs who were ready to work for less. Even with her good contacts there and a very good knowledge of the local language, after 20 years she was not willing to continue under these new, as she said, unfair conditions.

\section{Labour exploitation}

We identified three cases of severe labour exploitation (reporting 7 to 9 indicators) and six cases of labour exploitation (3 to 6), according to the stages of labour exploitation defined by the FRA [2015] and considering the nine indicators which ILO [2009] suggests. One respondent who suffered from severe labour exploitation identified it himself:

It was poor exploitation... I was promised one thing, and when I went there it turned out to be something completely different... Day off? There was no such thing... we had to work, wait, let me count, around 16 hours per day. (Interview 1) 
Eight of the respondents have worked in the agricultural sector, known to be among the most precarious sectors, for low wages and labouring excessive hours [Brougton, et al. 2016; Aleksynska et al. 2017, ILO 2014]. All three cases of severe labour exploitation identified were also in this sector.

Only one of our respondents experienced none of the indicators of labour exploitation in his employment abroad. We have identified 10 cases of labour exploitation, but only three of our respondents complained about their working conditions (those experiencing severe labour exploitation). Most of our respondents did not consider their working conditions problematic and neither complained nor tried to change them, as long as they received their earnings as promised. Their subjective perspective of fair work clearly differs from the legislative framework which we use to describe the phenomenon. This discrepancy raises the question of why it exists and if there is a relevant explanation for it.

The voice of the respondents differed among generations: a generation gap can be observed in terms of their knowledge about their labour rights. The respondents over the age of 40 (who had work experience before 1989) are more aware of how fair working conditions should be. In the interviews, they spoke about problematic working conditions more often, without being asked additional questions. The younger respondents (under 40) associate work mainly with income generation; working conditions were not present in their stories at first. They compared their labour experiences from the different jobs they had had according to the amount of money they were earning. In these cases, we needed to ask them more specifically about the working conditions in their places of work.

\section{Departure Arrangements and the Role of Supporting Networks}

Informal social networks were crucial for all 13 respondents' first departures. Their satisfaction with their labour experiences abroad depended on the type of network used. Respondents employing a strong network of family and close friends did not complain about their experiences of labour exploitation, although ILO indicators suggest they experienced it (Table 2). The fact that they had a support network gave them a feeling of security and the option of changing jobs if the conditions were no longer acceptable.

Most of the respondents were not the pioneer migrants in their families and went to EU countries where they had an already existing and stable social network. Six of them used a strong network abroad before departure; four - a medium one. Only three of the respondents used a weak network for their first departure. Thus, most of our respondents had access to social networks abroad that could provide 
assistance with travel arrangements and job offers upon arrival and minimise the risks of the migration action. Nine respondents who went somewhere where they already had an established network had no particular complaints about their working conditions abroad. They showed satisfaction with their working conditions and payment, although they mentioned the existence of various indicators of labour exploitation in the interviews. For example, almost all of them experienced long working hours and the absence of days off, as well as the lack of contracts or social security. In general, all nine respondents who were satisfied with their work abroad found their jobs with the help of a strong network of relatives who had already been working in the respective host country for several years. Those respondents were aware of the labour conditions they should expect before their departure. Their networks provided them with housing, job offers, and information and advice about their work, which compensated for their lack of local language proficiency and helped minimise the risk of their migration actions.

One respondent used a medium-strength network of friends abroad in order to find a job. He showed a higher dissatisfaction level than those respondents who used family connections prior to their migration actions. The respondent complained about his remuneration and the long hours he worked but, at the same time, he felt secure because his friends were there to support him if problems occurred:

I want to be in a place where I have friends nearby, you never know, there are all kinds of people and if you do not know the language and have some problems with your boss, you cannot leave without their help. (Interview 10)

This statement shows how social networks abroad compensate for migrants' vulnerabilities and reduce risk factors for exploitation to some degree.

\section{Use of weak social networks abroad}

The three respondents who were not satisfied with their working conditions and had complaints - about their working hours, the difficulty of their work, and, most of all, their remuneration - used weak network ties ('some people I know', acquaintances) in order to prepare for their departure. These networks did not support them further than travel arrangements:

They just left me there and went back. I did not see them afterwards. (Interview 1)

These three respondents shared that they had been deceived about the working conditions before their departure from Bulgaria. All of them had been misinformed about the working hours (much longer than eight hours per day) and the extended 
periods without days off, as well as the amount of the money they would receive, e.g., additional travel payments were taken from their wages. Furthermore, they described their payment as very low and less than they had expected. They tried complaining to their employers, but this did not change their situations. One of the respondents was promised a job as a driver but had to work as an agricultural worker on a farm. These respondents stayed in the host countries for a couple of months, as there was no possibility for them to leave on the spot because they were only paid in full at the end of the season or needed to save money for the return trip to Bulgaria. None of them knew the local language and the farms where they worked were in isolated areas. They could not get any support from their colleagues, who were in the same situation or worse:

There was a young family when I got there; the employer had their documents. (Interview 1)

There were some girls from Ukraine there and they never complained because they are not from the $E U$ and need visas. (Interview 4)

The case of workers unsupported by strong networks illustrates how risk factors become exacerbated due to their inability to redress the situations of labour exploitation they find themselves trapped in.

These findings are in line with those of FRA [2015], which suggests that people in precarious situations are willing to go along with exploitative labour practices as a means of overcoming financial hardships in their home countries, though their experience depends on the type of support networks made up of their own community members within the host country.

The use of weak networks before departure and the abuses such networks foster represent a serious risk of labour exploitation among Bulgarians in other EU countries. Thus, there is a need for prevention work in the home country to enable migrants to make informed choices about their migration actions. Two of the three respondents who used a weak network in their first migration action used a stronger network for the arrangement of their second labour migration action in the EU: one used a medium network and the other used a state agency.

\section{CONCLUSION}

In this article we drew links between precarious work and labour exploitation as an exacerbated form of precariousness. While precarious migrant work practices have been demonstrated already in the literature [Markova 2007; McDowell et al. 2009], we reconstructed the development of the process that could lead to labour exploitation. This qualitative study on Bulgarian migrants in other EU 
countries shows how experiences of precarious working conditions can lead to labour exploitation. As Bulgaria's economy, with the lowest income per capita, is still the weakest among EU member-states, its economic difficulties are the most common factor creating and shaping migrant workers' vulnerability.

Incorporating migration theories and the concept of social networks, we demonstrated that strong social ties [Massey 1993, Boyd et al. 2012, Granovetter 1973] are the main mechanisms for minimising the subjective feeling of being exploited; they are seen as a support net which can catch you if the job goes really badly [Samers 2010]. Utilising those networks, low-skilled Bulgarian migrants partially compensate for their vulnerabilities due to economic status, lack of state protection, and lack of language skills. The mobilisation of weak social networks can affect individual experiences and job satisfaction negatively: the respondents using weak social networks for their migration have been employed in situations involving deceptive practices and leading to more severe labour exploitation. In spite of occasional or frequent dissatisfaction and disappointment felt by migrant workers, when comparing the two alternatives - home or abroad - they continue engaging in migration actions in order to achieve better financial stability than what is feasible in Bulgaria.

We are aware of the limitations of the qualitative approach and pilot character of the study. However, we shall continue these interviews with the aim of expanding the group and further diversifying its profile of respondents studied, with a special focus on age. Other available statistical evidence in some of the host countries could also be analysed.

Our findings relate to the role of social networks as well as particular policy implications, not only for the relevant public administrations but also for civic organisations and trade unions, e.g., informative campaigns about the risks of exploitation. Thus, the Bulgarian migrant worker community's awareness of labour rights is positioned as a mechanism for the prevention of labour exploitation in other EU countries.

The free movement of European citizens will no doubt sustain the process of inter-European migration facilitated by circular, seasonal, or temporary migration schemes. While this process could benefit some groups, others facing particular vulnerabilities could be exposed to exploitation practices that undermine their labour rights and even human rights.

\section{Acknowledgements}

We thank Adam Mrozowicki, Eugenia Markova and the anonymous reviewers for their comments and suggestions. 


\section{REFERENCES}

Abrams Laura S. 2010. "Sampling 'hard to reach' populations in qualitative research. The Case of incarcerated youth". Qualitative Social Work 9(4): 536-550.

Aleksynska Mariya, Samia Kazi Aoul, Veronica Petrencu. 2017. "Deficiencies in conditions of work as a cost to labor migration: Concepts, extent, and implications". Knomad: Working Paper 28.

Alpha Research. 2015. Bulgarian labour migration. Sofia: Alpha Research.

Beck Ulrich. 2000. The brave new world of work. Cambridge: Polity Press.

Boyd Monica, Joanne Nowak. 2012. Social Networks and international migration. In: An introduction to international migration studies, M. Martiniello, J. Rath, (eds.), 77-103. Amsterdam: Amsterdam University Press.

Brougton Andrea, Martha Green, Catherine Rickard, Sam Swift, Werner Eichhorst, Iga Magda, Piotr Lewandowski, Roma Keister, Dovile Jonaviciene, Nuria Elena Ramos Martin, Daphne Valsamis, Frank Tros. 2016. Precarious employment in Europe: Patterns, trends and policy strategies. Brussels: European Parliament.

http://www.europarl.europa.eu/RegData/etudes/STUD/2016/587285/IPOL_STU(2016)587285 EN.pdf [access: 21.07.2018].

Cassarino Jean-Pierre. 2004. "Theorising return migration: The conceptual approach to return migration revisited". International Journal on Multicultural Societies 6(2): 253-279.

Dustmann Christian, Joseph-Simon Görlach. 2015. "The economics of temporary migrations". The Journal of Economic Literature 54(1): 98-136.

Engbersen Godfried, Arjen Leerkes, Izabela Grabowska-Lusinska, Erik Snel and Jack Burgers. 2013. "On the differential attachments of migrants from Central and Eastern Europe: A typology of labour migration". Journal of Ethnic and Migration Studies 39(6): 959-981.

Eurofound. 2014. Labour migration in the EU: Recent trends and policies. Dublin: Eurofound. http://digitalcommons.ilr.cornell.edu/cgi/viewcontent.cgi?article=1421\&context=intl [access: 05.10.2017].

European Parliament Committee on Women's Rights and Gender Equality. 2010. Report A7-0264/2010.

http://www.europarl.europa.eu/sides/getDoc.do?pubRef=-//EP//NONSGML+REPORT+A72010-0264+0+DOC+PDF+V0//EN [access: 05.02.2018]

Evans John, Euan Gibb. 2009. “Moving from precarious employment to decent work”. Geneva: ILO.

Flick Uwe. 2009. An introduction to qualitative research. London: SAGE.

Flyvbjerg Bent. 2006. "Five misunderstandings about case-study research". Qualitative Inquiry 12(2): 219-245.

FRA. 2015. Severe labour exploitation: workers moving within or into the European Union. Vienna: FRA (European Union Agency for Fundamental Rights).

Granovetter Mark. 1973. "The strength of weak ties”. American Journal of Sociology 78(6): $1360-1380$.

ILO. 2009. "Explanations for indicators of trafficking for labour exploitation". ILO.

http://www.ilo.org/wcmsp5/groups/public/---ed_norm/---declaration/documents/publication/ wcms_105035.pdf [access: 11.04.2017]

ILO. 2014. "Profits and poverty: the economics of forced labour". International Labour Office: Geneva. 
http://www.ilo.org/wcmsp5/groups/public/---ed_norm/---declaration/documents/publication/ wcms_243391.pdf [access: 11.04.2017].

Kaczmarczyk Pawel, Marek Okólski. 2005. International migration in Central and Eastern Europe - Current and future trends. United Nations. UN/POP/PD/2005/12.

King Russell. 2012. "Theories and typologies of migration: An overview and a primer". Willy Brandt Series of Working Papers in International Migration and Ethnic Relations 3/12.

Keller Berndt, Hartmut Seifert. 2013. Atypische Beschäftigung zwischen Prekarität und Normalität. Entwicklung, Strukturen und Bestimmungsgründe im Überblick. Berlin: Sigma.

Kirov Vassil, Pernille Hohnen. 2015. "Trade unions strategies to address inclusion of vulnerable employees in 'anchored' services in Europe". International Journal of Manpower 36(6): 848-873.

Krasteva Anna. 2006. "Post-communist discovery of immigration: the case of Bulgaria". SEER: Journal for Labour and Social Affairs in Eastern Europe 9(2): 25-34.

Markova Evgenia, Barry Relly. 2007. "Bulgarian migrant remittances and legal status: some micro-level evidence from Madrid". South-Eastern Europe Journal of Economics 1:55-69.

McCann Deirdre, Judy Fudge. 2017. "Unacceptable forms of work: a multidimensional model”. International labour review 156(2):147-184.

McDowell, Linda, Adina Batnitzky, and Sarah Dyer. 2009. "Precarious work and economic migration: emerging immigrant divisions of labour in Greater London's service sector". International Journal of Urban and Regional Research 33(1): 3-25.

McKay Sonia, Steve Jefferys, Anna Paraskevopoulou, Janoj Keles. 2012. Study on precarious work and social rights. London: Metropolitan University.

Nikolova Desislava, Zornica Slavova, Kalojan Stoykova, Peter Ganev, Javor Aleksiev. 2016. Poverty in Bulgaria, education and employment as factors for income inequality. Sofia: Institute for market economy (Николова Д., Славова 3., Стайков К., Ганев П., Алексиев Я., (2016) Бедността в България, Образованието и заетостта като фактори за доходите и неравенството, Институт за пазарна икономика, София).

National Statistical Institute. 2011. "Census 2011 final data” (Национален статистически институт (2011) Преброяване 2011, окончателни данни), available at: http:/www.nsi.bg/ sites/default/files/files/pressreleases/Census2011final.pdf [access: 11.04.2017].

Organisation for Economic Cooperation and Development. 2008. International migration outlook 2008, OECD Publishing.

Ranci Costanzo. 2011. "The political economy of social vulnerability. The social and political determinants of new social risks in western European countries". Working papers du Programme Villes \& territoires 2011(4). Paris: Sciences Po.

Samers Michael. 2010. Migration. London: Routledge.

Standing Guy. 2011. The precariat. The new dangerous class. London and NY: Bloomsbury Academic.

Stark Odder. 1991. The migration of labor. Cambridge, Mass.: Basil Blackwell.

Stone Katherine. 2005. "Flexibilization, globalization, and privatization: Three challenges to labor rights in our time". Osgoode Hall Law Journal Fall 2005 (05-19). UCLA: School of Law.

Trif Aurora, Aristea Koukiadaki, Marta Kahancova. 2016. The rise of the dual labour market: fighting precarious employment in the new member states through industrial relations (PRECARIR). Comparative report, Brussels: European Commission.

Walk free. 2016. The global slavery index. Australia: The Minderoo Foundation Pty Ltd. 
Williams Colin, Ioana Horodnic. 2015. "Evaluating the prevalence of the undeclared economy in Central and Eastern Europe: An institutional asymmetry perspective". European Journal of Industrial Relations 21(2): 389-406.

Zwolinski Matt, Alan Wertheimer. 2017. Exploitation. Stanford Encyclopedia of Philosophy. https://plato.stanford.edu/entries/exploitation/ [access: 13.10.2017].

\section{Maria Velizarova}

Vassil Kirov

\section{WYZYSK BULGARSKICH MIGRANTÓW W EUROPIE: MECHANIZMY RADZENIA SOBIE}

Streszczenie

Wyzysk pracowników i jego najbardziej wyraziste formy, jakimi są praca przymusowa czy przemyt ludzi, nie są zjawiskami nowymi. Są one obecne w całej Europie Środkowo-Wschodniej, w tym w szczególności w Bułgarii. Artykuł analizuje mechanizmy wykorzystywane przez emigrantów w celu poradzenia sobie z takiego typu wyzwaniami na rynku pracy. Analiza opiera się na wywiadach jakościowych z niskowykwalifikowanymi emigrantami z Bułgarii w krajach UE. Silne sieci społeczne wykorzystywane w czasie pierwszych działań migracyjnych uznane zostają za mechanizm, który ogranicza ryzyko wyzysku.

Słowa kluczowe: wyzysk pracowników, praca prekaryjna, migracja, Bułgaria, narażenie na ryzyko, sieci społeczne 